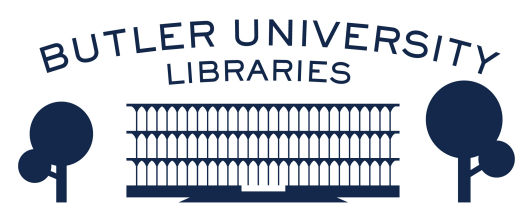

Journal of Hindu-Christian Studies

January 1999

\title{
Book Review: "No Other Gods: Christian Belief in Dialogue with Buddhism, Hinduism, and Islam"
}

Lance E. Nelson

Follow this and additional works at: https://digitalcommons.butler.edu/jhcs

Part of the Religion Commons

\section{Recommended Citation}

Nelson, Lance E. (1999) "Book Review: "No Other Gods: Christian Belief in Dialogue with Buddhism, Hinduism, and Islam"," Journal of Hindu-Christian Studies: Vol. 12, Article 17.

Available at: https://doi.org/10.7825/2164-6279.1215

The Journal of Hindu-Christian Studies is a publication of the Society for Hindu-Christian Studies. The digital version is made available by Digital Commons @ Butler University. For questions about the Journal or the Society, please contact cbauman@butler.edu. For more information about Digital Commons @ Butler University, please contact digitalscholarship@butler.edu. 


\section{No Other Gods: Christian Belief in Dialogue with Buddhism, Hinduism, and Islam. Hendrik Vroom. Grand Rapids, MI: Eerdmans, 1996, vii $+174 \mathrm{pp}$.}

HENDRIK VROOM IS Professor of Philosophy of Religion at the Vrije Universiteit in Amsterdam. His book is an exercise in philosophical theology that seeks to exemplify a "critical" approach to interreligious dialogue. This approach, while avowing readiness to learn from dialogue partners, does not rule out asking probing questions or raising issues of truth. Indeed, Vroom feels called to "weigh" the traditions he engages, noting "disadvantages" as well as "advantages". Nor does he exclude from his dialogical enterprise the quest to justify his Christian vision. One religion can know more about God and salvation than another, and for Vroom, God is most fully revealed in Christ. There is no neutral standard for judging religious insights. The fact of difference and the need for understanding call for a "public debate" in which knowledgeable critiques are formed and responded to by all concerned.

Chapters 2-4 of the book approach Buddhism, Hinduism, and Islam from the stance of this critical dialogue. The "strong points" of Buddhism include most especially the Buddhist emphasis on personal spiritual formation. Vroom is suspicious, however, of what he sees as Buddhism's moral ambiguity. Buddhist enlightenment situates one beyond good and evil, and this, Vroom fears, tends to relativize moral categories. When the secular world is identical with the absolute, all things being utterly interrelated, any clear distinction between justice and injustice is lost. This problem is compounded by Buddhism's desire to achieve a stance that excludes suffering and its consequent ethic of detachment.

Vroom is more, perhaps most, uncomfortable with Hinduism, complaining- after a valiant attempt to make sense of its multiplicity of divine forms - that "the order among the Hindu gods is not clear" (53). While acknowledging the compellingness of the Hindu "holism" that sees human beings and nature as inseparable from the sacred, and admiring the strong Hindu sense of intimacy with the divine, Vroom finds the same moral weakness here that he sees in Buddhism: "Should the whole of reality emanate from one place, then evil also has a place, so that it too becomes more or less meaningful" (67). The moral situation is exacerbated by the inclusion of the social order of caste as an essential element of the sacred whole. Moral distinctions are too closely associated with notions of caste duty, and "it is difficult to find a point outside the order of society from which it can be criticized" (66). Despite the "monistic" view, people are not cherished equally as images of the divine; freedom in Hinduism is found only in transcendence of the world, so there is no socially oriented vision of salvation but only one of private emancipation. Vroom devotes much energy to a critique of Hindu conceptions of karma and reincarnation, which he - like many Christian writers - sees as legitimating social inequality and fostering resignation in the face of injustice. Perhaps the most startling notion in the book is introduced here: the idea that Hindus have an obligation to produce more evidence in the face of the "weakness of the proofs for reincarnation" (79).

With Islam, Vroom is back in the for him more congenial region of prophetic religion, where good and evil are more clearly drawn. He finds much that is laudable in the Muslim effort to bring all aspects of life under the sway of the one God. His central question is whether Muslims know "the same God" and, if so, whether they do so more or less truly than Christians. He answers this question on logical and textual grounds, concluding that there is so much agreement between what Muslims and Christians say about God that Muslims do know the same God, but, since they do not know God as revealed in the 
"history of the cross", Christians are able to know more truly. Vroom allows that Muhammad, though not a prophet in the full biblical sense, did have experience of God. Where it does not contradict the Bible, the Koran can thus be read "as the result of reflections on God's meeting with Muhammad" (124).

In his final chapter, Vroom asks bold and synthesizing questions. On the issue of whether Christians have access to knowledge about God not available to others, he restates his affirmative answer. However, this does not mean for him that Christians have the whole of knowledge and others have none. As to whether there is salvation beyond the Christian fold, he answers also in the affirmative: other traditions may provide access to salvation, or at least forms of salvation. Examining what they say about God (or the absolute), he concludes that, while the faithful of all the great traditions may experience transcendence of some kind, "not all religions worship the same God" (150). Buddhists and nondualist Hindus are distinctly disadvantaged in this respect. (Theistic Hindus receive more sympathy, but their case remains uncertain.) The author does allow that some who may thus be off the mark in their worship and meditation may still, no matter how mistakenly, intend the biblical God.

Vroom shows considerable respect and even at points admiration for his Buddhist, Hindu, and Muslim dialogue partners, but one is left with a sense that their voice has not really been attended to. Moreover, one senses an overconfidence, typical among Western philosophers, that enables Vroom to come to broad conclusions based entirely on the study of texts in translation and the application of logic. The author warns against over-determining God, but still wants to limit the divine and its expression through application of the law of noncontradiction. I would prefer a more careful method of prolonged dialogue with a single tradition, which would involve learning the languages, careful study of original texts, living among the believers, and so on. The results of such an approach - as seen, for example, in the work of Francis X. Clooney, SJ - are less sweeping. Indeed they are considerably more limited. Nevertheless, they are more authentic. Still, the questions raised by Vroom, though not really new, are important ones that have yet to be fully addressed. The critical edge maintains respect and provokes thought.

Lance E. Nelson University of San Diego

\section{Ascent to the Depth of the Heart. The Spiritual Diary (1948-1973) of Swami Abhishiktananda (Dom H. Le Saux). A Selection edited with introduction and notes by Raimon Panikkar. English Translation by David Fleming and James Stuart. ISPCK Delhi 1998. xxxvi +410 pp.}

\begin{abstract}
HENRI LE SAUX (1910-1973), a French Benedictine monk, known as Swami Abhishiktananda, came to India in response to an inner call to a contemplative life, in tune with Indian tradition. His struggles and deep thoughts as recorded in his diary are placed before the readers through this publication. The title of this book is meant to suggest going beyond all the dualities, by using the paradox of the ascent to the depth
\end{abstract}

(xii). Devoted friends of Abhishiktananda have taken meticulous care to translate the original text into English.

Abhishiktananda is already known to the public through his writings. But then R. Panikkar in his perceptive introduction summing up the background of the author, points out the difference between the diary and the published writings:

In his books he is aware of his role as a 